\title{
COLONIZATION of Rubus glaucus BENTH BY AZORHIZOBIUM CAULINODANS ORS571 USIG A FLAVONOIDE NARINGENINA
}

\author{
Cancino-Escalante GO1', Cancino SE, Quevedo-García E \\ ${ }^{1}$ Plant Science lecture, Biology Department, Universidad de Pamplona
}

\begin{abstract}
Root systems of two Andean blackberry materials (thorn and thornless) of Rubus glaucus Benth cultured in vitro in the presence of five treatments (four flavonoids and one control) were inoculated with Azorhizobium caulinodans ORS571 (pXLGD4) (a strain carrying the lacZ reporter gene which facilitated the detection of bacterial colonization). Evaluation of colonization effectiveness for each treatment was done by means of application of experimental design measuring frequency and intensity parameters. Statistical analysis showed differences at comparing flavonoids vs. control and the overall higher effectiveness of the flavonoid naringenin. Observation of colonization was made by light and electron microscope confirming internal colonization of Andean blackberry roots by $A$. caulinodans. This is the first work demonstrating root colonization of R.glaucus by azorhizobia and therefore settling the basis for future investigations and scientific applications related to interaction with plant growth-promoting bacteria under the effect of flavonoids, along with possible implications of common benefit for non-legume crops in the northwest region of Colombia.
\end{abstract}

Key Words: Azorhizobium caulinodans ORS571, Andean blackberry, flavonoids, LacZ, lateral roots, naringenin.

Evaluación de la colonización de raíces de plantas in vitro de Rubus glaucus Benth (mora de Castilla) por Azorhizobium caulinodans ORS571 empleando el flavonide naringenin

\section{Resumen}




\section{6}

El sistema radical de dos cultivares (con espinas y sin espinas) de $R$ glaucus cultivado in vitro fueron sometidos a cinco tratamientos (cuatro flavonoides y un control) y se inocularon con Azorhizobium caulinodans ORS ( $\mathrm{pXLGD4)}$ (una cepa que posee el gen reportero lacZ, el cual facilito la detección de la colonización bacteriana). La evaluación de la efectividad de la colonización para cada tratamiento fue determinada mediante la aplicación de un diseño experimental basado en la quantificacion de la frecuencia e intensidad como parámetros. El análisis estadístico no parametrico de las variables evaluadas determino diferencias significativas al comparar los flavonoides con el control. Igualmente fue evidente la alta eficiencia en la colonización del flavonoide naringenina. Los análisis de colonización se basaron en las observaciones efectuadas mediante microscopia de luz y electrónica de alta resolución, confirmando la colonización de las raíces de mora de Castilla por azorhizobia. La presente investigación se constituye en el primer trabajo que demuestra la colonización de mora de castilla por azorhizobia y establece las bases para futuras investigaciones y aplicaciones científicas relacionadas con bacterias promotoras del crecimiento vegetal bajo el efecto de flavonoides en cultivos de especies no leguminosas.

Palabras clave: Azorhizobium caulinodans ORS571, mora de castilla, flavonoides, LacZ, raíces laterales, naringenina.

*Para citar este artículo: Cancino-Escalante GO, Cancino SE, Quevedo-García E.Colonization of Rubus glaucus Benth by Azorhizobium caulinodans ORS571 usig a flavonoide naringenina. Revista Bistua. 2016.14(2):15-26

+ Autor para el envió de correspondencia y la solicitud de las separatas: Cancino-Escalante GO, Biology Department, Universidad de Pamplona,Pamplona, Norte de Santander, Colombia South America E-mail:gcancino@unipamplona.edu.co 
17

\section{INTRODUCTION}

Nitrogen is an essential plant nutrient and is commonly deficient in soils thus reducing agricultural yields. World consumption of nitrogen fertilizer can average 112.909 million tons/year by 2015 (1) which in many cases can cause environmental damage such as groundwater pollution, increase in atmospheric nitrous oxide (a "greenhouse" gas) and chemical spills. Biological nitrogen fixation (BNF) is an alternative to fertilizers as it can provide chemically fixed nitrogen, and rhizobial inoculants (known for their capacity to reduce atmospheric nitrogen) have been applied frequently as biofertilizers (2).

Rhizobia are frequent rhizosphere colonizers of a wide range of plants such as wheat, oilseed rape and rice. For example, among the rhizobia used, Azorhizobium caulinodans is of particular interest as it was able to fix nitrogen in free-living state without differentiation into bacteroids of tropical legumes such as Sesbania rostrata (3). The use of improved host-rhizobia combination has a great potential to increase nitrogen fixation in non leguminous plants. Interaction between a range of traits and nitrogen fixing symbiosis can make an important contribution to the aim of extending the benefits of BNF to no leguminous such as $R$ glaucus. In Colombia has been increasing Andean blackberry production and area planted, according to statistics from (4), being considered as a fruit with opportunities for cultivation in Colombia, for both domestic market supply and for export. $R$. glaucus belongs to the genus Rubus, which with about 400 species distributed in America, Europe, Africa and Asia constitutes one of the most genetically diverse genera in the tropical high land mountains of Colombia (5). In this country the main species cultivated of Andean blackberry is $R$. glaucus, is known as mora de Castilla whose origin comprising areas high tropical America (6). In Colombia there is great variability of this species in size, color and fruit quality, which possibly occurred a selection practiced in ancient times from wild plants (7). Biological nitrogen fixation offers an economical and ecological alternative of reducing nitrogen fertilizer thus improving the quality and quantity of internal resources. Therefore, the present study examined whether $A$. caulinodans was able to colonize lateral roots of in vitro plants of Andean blackberry and whether exogenous flavonoids affect the colonization of $R$. glaucus. 
18

\section{MATERIAL AND METHODS}

Plant Material.Cuttings of two materials of $R$. glaucus (thorn and thornless) supplied by plant in vitro culture laboratory at the University of Pamplona. These explants were disinfected superficially with commercial bleach at $3.0 \%(\mathrm{v} / \mathrm{v})$ by immersion for 15 minutes. After superficial disinfection the cuttings were washed for three consecutive times in sterile water and transferred aseptically to sterile flasks each one containing $25 \mathrm{ml}$ MS medium (8) semi solidified with $0.19 \%(\mathrm{w} / \mathrm{v})$ phytagel (Sigma (B). In all media, $\mathrm{pH}$ was adjusted to 5.8 with dilute $\mathrm{HCl}$ or $\mathrm{KOH}$ prior to autoclaving for $15 \mathrm{~min}$ at $121^{\circ} \mathrm{C}$. Cultures were incubated at room with fluorescent light $(250$ micro Einsteins of lighting $\mathrm{m}^{-2} \mathrm{~s}^{-1}$ ) to $20{ }^{\circ} \mathrm{C}$ with a photoperiod of $16 \mathrm{~h}$, until they developed lateral roots with an average of $5 \mathrm{~cm} \quad(60$ days approximately).

\section{Preparation of flavonoid solutions}

Chrysin

(5,7-dihydroxy-flavone), naringenin (5,7,4'-trihydroxyflavanone), quercetin $\left(3,3^{\prime}, 4^{\prime}, 5,7-\right.$ pentahydroxy-flavona), and daidzein (7,4'-dihydroxy-isoflavone) (Sigma $\AA)$, were diluted individually in a concentration of $10 \mathrm{mg} \mathrm{ml}^{-1}$ of dimetil sulfoxide (DMSO) (Sigma ${ }^{\circledR}$ ) inside microtubes $(1.5 \mathrm{ml})$. Dimetil sulfoxide without flavonoids was used as control. Filter sterilized flavonoids were incorporated into autoclaved plant growth medium (MS) (Murashige and Skoog, 1962) in a final concentration of 25, 50 and $75 \mu \mathrm{M}$, according to previous literature $(9,10)$.

\section{Azorhizobiae culture and detection of B-galactosidase activity associated with plant roots}

The strain $A$. caulinodans ORS571 (pXLGD4) (supplied by Dr Kenneth O'Callaghan, Bioscience School of the University of Nottingham, England) that contains the constituent reporter gene lacZ, was cultivated in triptone (Difco)-glucose (Sigma (B)yeast extract (Sigma $\AA$ ) (TGYE) (11) semi solidified with (Bacto-agar Difco) $1 \%(\mathrm{w} / \mathrm{v})(\mathrm{pH} 6.8)$, with $2.5 \mu \mathrm{ml}^{-1}$ of water solution of tetracycline (Sigma (B) at $10 \mathrm{mg} / \mathrm{ml}$ ), for 3 days and incubated at $28^{\circ} \mathrm{C}$. Each plant was inoculated with $200 \mu$ l of azorhizobiae suspension in TGYE $(600 \mathrm{OD})$. The plants were removed after 21 days and the lateral number of roots colonized by azorhizobiae was quantified by the detection of the $B$ galactosidase activity associated with plant roots. Histochemical staining of bacterial B-galactosidase activity was performed using X-Gal (5-bromo-4chloro-3-indolyl-B-D-

galactopyranoside) as substrate, as described by (12). The root system was prefixed in $3 \%(\mathrm{v} / \mathrm{v})$ 
19

glutaraldehide (Sigma $\AA$ ) - sodium phosphate buffer (Sigma $\left.{ }^{\circledR}\right) 0.1 \mathrm{M}(\mathrm{pH}$ 7.2) at $21^{\circ} \mathrm{C}$ for 3.5 hours, to prevent endogenous activity of the $B$ galactosidase enzyme (9).

\section{Microscopic Procedures}

Root pieces of interest were dissected from whole roots already stained for B-galactosidase and fixed again in 2 volumes glutaraldehyde (EM grade): 98 volumes water in $120 \mathrm{~mol} \mathrm{~m}^{-3}$ sodium cacodylate buffer $(\mathrm{pH} 7.2)$ overnight at $4 \stackrel{\circ}{\circ} \mathrm{C}$. Fixed specimens were dehydrated in ethanol series and progressively embedded in LR white medium grade resin using gelatin capsules. Polymerization was performed at $68^{\circ} \mathrm{C}$ for $24 \mathrm{~h}$. Sections were cut and collected on glass slides and stained with a mixture of $10 \mathrm{~kg}$ toluidine blue, $20 \mathrm{~kg}$ methylene blue and $10 \mathrm{~kg}$ sodium tetraborate per $\mathrm{m}^{3}$ (13). The microscopic analysis of the azorhizibiae preparations of the roots taken from the experiments was carried out in accordance with Trouvelot's method (14). Electronic microscopic observations were performed on samples fixed and embedded, as described above, but with the additional step of postfixation in $10 \mathrm{~kg}$ osmium tetroxide and 120 mol sodium cacodylate buffer ( $\mathrm{pH} 7.2)$ per $\mathrm{m}^{3}$, prior to dehydration $(15,16)$.
The initial weight of the in vitro plants was recorded and then reweighed after 21d using different flavonoids in the culture medium (MS) at the concentration of $50 \mu \mathrm{M}$. [Growth Weight Rate $=(($ Initial weight - Final weight/Initial weight) $x$ 100)].

\section{Experimental design data analysis}

The experimental design was comprised of 4 different flavonoids and one control (for a total of 5 treatments), applied to 2 cultivars of blackberry (thorn and thornless) , 10 plants per variety $(n=10), 3$ replicas, and its respective lateral roots as unit of sampling according to Mycocalc computer program (14). For quantification of root colonization the variables measured in the present study were:

\footnotetext{
* Bacterial colonization in the lateral root system (BCLRS).$$
B C L R S=\frac{\text { number of colonized lateral roots }}{\text { total number of lateral roots }} \times 100
$$

* Bacterial intensity of colonization in the lateral root system (BICLRS).
}

\section{Plant biomass}


20

$$
B I C L R S=\frac{[(85 \mathrm{x} \mathrm{n} 3)+(50 \times \mathrm{n} 2)+(15 \mathrm{x} \mathrm{n} 1)]}{\text { total number of lateral roots }} \times 100
$$

- Bacterial intensity of colonization in each lateral root (BICELR).

$B I C E L R=\frac{\text { BICLRS } \mathrm{x} \text { (total number of lateral roots) }}{\text { number of colonized lateral roots }}$

The percentages data of the bacterial and intensity of colonization were submitted to the Anderson-Darling test to verify the homogeneity of the variance. The results showed a noncontinuous distribution, of which were submitted to the Kruskal-Wallis test using the statistical software IBM SPSS. Version 19. Means and standard error (SE) were used throughout.

\section{RESULTS}

\section{Colonization of carnation roots by Azorhizobium caulinodans}

Bacterial colonization of carnation roots could be observed histochemically as a blue precipitate resulting from degradation of X-gal due to the constitutively expressed lacZ reporter gene carried by pXLGD4. In vitro 14 d-old blackberry plants were found to be colonized by A. caulinodans strain ORS571 (pXLGD4) on the root surface, at root tips and more frequently on the bases of lateral roots (Figure 1). Sections cut from the lateral root system when observed by light and high resolution microscopy showed that the bacteria was able to colonize, grow and divide within intercellular spaces of the lateral roots of blackberry in vitro plants(Figure 2).

Flavonoid stimulation of R.glaucus lateral root colonization by Azorhizobium caulinodans

The process of rhizobial infection thread formation and nodulation in legumes is due to flavonoid signal molecules. The main objective of this study was to determine whether such molecules are involved in lateral root colonization in two varieties (thorn and thornless) of the Andean Blackberry. Three different concentrations $(25 \mu \mathrm{M}, 50 \mu \mathrm{M}, 75$ $\mu \mathrm{M})$ of four flavonoids were incorporated into the plant growth medium. From the three variables evaluated it was found that the flavanone naringenin $(50 \mu \mathrm{M})$ was more effective as it significantly stimulated colonization $(\mathrm{P}=0.005, \mathrm{n}=$ $10)$ of lateral roots when compared to the other three flavonoids. Concentrations of $25 \mu \mathrm{M}$ and $75 \mu \mathrm{M}$ of naringenin and the other three flavonoids had no significant stimulating effect (data not shown). According to the results obtained in the mean comparison tests in the BCLRS variables (Bacterial colonization in the lateral root system) 
21

all the flavonoids showed higher frequency of colonization when compared to control confirming its effectiveness in the promotion of colonization by $A$. caulinodans (Figure 1). The results in the bacterial colonization intensity variables [Bacterial intensity of colonization in the lateral root system (BICLRS); Bacterial intensity of colonization in each lateral root (BICELR)] also indicated an overall greater efficacy of naringenin in the 2 cultivars of R.glaucus (Figure 1). Kruskall-Wallis one way non-parametric test did not show any significant pairwise differences between materials.

\section{Flavonoids as promoters of plant} growth in R.glaucus

A. caulinodans promoted growth weight rate in in vitro plants of the two cultivars of Andean Blackberry. Nevertheless, when the culture medium was supplemented with the different flavonoids (chrysin, quercetin, daidzein and naringenin) growth weight rate increased. The results showed that at the concentration of $50 \mu \mathrm{M}$ for both materials naringenin (thorn, 5,83g) and chrysin (hornless, 8,17g), growth weight rate was significantly higher when compared to the other flavonoids tested.

\section{DISCUSSION}

In general, with the exception of induction of crown gall disease by agrobacteria and rhizobial nodulation of legumes, there has not been an extensive investigation of the bacterial infection of the root system in tropical fruits plants $(17,18)$. Most studies are focused on genes that are not probably involved in the plant rootsbacteria interactions (19) Plantgrowth-promoting rhizobacteria are a potentially beneficial microorganisms (20) therefore, the results obtained in this study with respect to the invasion of the roots of non-legumes by bacteria are most welcome and could be of significant contribution to the research literature on plantassociated diazotrophs.

In the present study it was shown for the first time the presence of the intercellular rhizobial root colonization of the non-legume $R$. glaucus. The detection of bacterial colonization was facilitated by the use of the lacZ reporter gen as a marker. It was observed that $A$. caulinodans colonized the R.glaucus plants root surface, root tips and more frequently the natural fissures resulting from the lateral roots (Figure 1,), as reported by (21) in wheat, (22) in Brassica napus (23) in Arabidopsis thaliana. The way by which bacteria colonize root R.glaucus in in vitro plants could be the same as observed in many 
22

tropical legumes (Sesbania rostrata, Netunia sp, Stylosanthes, Aeschynomene and Arachis). The bacteria enter via cracks the lateral roots and colonize large intercelluar spaces (infection pockets). This mechanism is characterized by local cell death due to an ethylene induced oxidative burst response that opens up a pocket within which the bacteria can live $(24,25,26,27)$. The data also confirmed that the concentration of the different flavonoids $(50 \mu \mathrm{M})$ in the plant medium was adequate to promote the carnation roots colonization by azorhizobia in a more effective way than the roots inoculated in absence of flavonoids. Naringenin showed to be the most effective flavonoid promoting the colonization of R.glaucus (Figure 1), confirming the results obtained in previous studies with other plant species Wheat (21); B.napus(10), Arabidopsis thaliana (28) and Passiflora mollisisma (18). The effectiveness of the flavonoids in the increase of bacterial colonization could be that when added to the culture medium the amount of extracellular proteins produced may increase therefore, inducing higher activity of bacterial cell growth (29). In the case of plant cell growth, it may be that flavonoids do not influence bacterial cell growth directly; plants might have modified the exogenous flavonoid, thus stimulating bacterial colonization (22). The mechanisms responsible for the stimulation of plant cell growth by flavonoids is still unknown and we cannot presently determine whether plants and/or bacteria are the targets of the flavonoid effect (Figure 1). Previous studies on azorhizobia and nonlegumes interactions have shown that naringenin does not act as a carbon source for bacterial colonization as succinate (carbon sourced favoured by $A$. caulinodans) does not promote colonization (21). Another important finding in this study was the effect of the bacteria and the flavonoid naringenin on plant growth of in vitro Andean Blackberry plants. Plant growth-promoting bacteria can affect plant growth either directly or indirectly. Several different mechanisms of direct stimulation could have occurred. For example, the bacteria may have a) synthesized siderophores that solubilize and sequester iron from the medium and transferred it to the plant cells; b) fixed atmospheric nitrogen that was used by the plant; c) synthesized enzymes that could modulate the level of the plant hormone ethylene; d) synthesized phytohormones (e.g. auxin, cytokinin, giberellin) that could have enhanced several stages of plant growth; or e) solubilized minerals (e.g. phosphorus) that were used by the plant (30). With the 
23

present study it was shown for the first time the effectiveness of the flavonoids promoting root colonization by diazotrophic bacteria in two cultivars of $R$. glaucus. It will be interesting to study $A$. caulinodans intercellular colonization further and to determine whether it is capable of nitrogen fixation under experimental and glasshouse conditions in these two materials.

\section{Acknowledgements}

The authors wish to thank Doctor Ken O'Callaghan for supplying the strain A. caulinodans. This research was funded by Universidad de Pamplona, Colombia.

\section{References}

1.-FAO, 2011. Current world fertilizer trends and outlook to 2015. ftp://ftp.fao.org/ag/agp/docs/cwfto15.pdf.

2.-Lodwig E. and Poole P. 2003. Metabolism of Rhizobium bacteroids. Critical Reviews in Plant Science 22(1):37-78.

3.-Kitts C. \& Ludwig R 1994. Azorhizobium caulinodans respires with at least 4 terminal oxidases. Journal of Bacteriology. 176:886-895.

4.-Agronet, 2015. Red de Información y Comunicación Estratégica del Sector Agropecuario

Colombia..http://www.agronet.gov.co/agr
onetweb1/Peque\%C3\%B1osproductores.

aspx.

5.-Clark, J., y Finn, Ch. (2011). Blackberry Breeding and

Genetics.http://www.globalsciencebooks.i nfo/JournalsSup/images/Sample/FVCSB

5\%28S11\%2 927- 430.pdf.

6.-Franco, G., Giraldo, M. 2002. El cultivo de la mora. Quinta Edición corregida. Manual de asistencia Técnica. CORPOICA, Federación Nacional de Cafeteros de Colombia, SENA, Comité Técnico Agropecuario de Risaralda, UMATA, Risaralda. $81 \mathrm{p}$.

7.-Castro, D., Díaz, J., Montoya, J., \& Ríos, D. (2006). Micropropagación de especies de interés hortícola y forestal en bioreactores de inmersion temporal. Revista Universidad Católica De Oriente, 1, $63-71$.

8.-Murashige T, Skoog F (1962) A revised medium for rapid growth and bioassays with tobacco tissue cultures. Physiol Plant 15:473-497.

9.-Gopalaswamy G., Kannaiyan S, O'Callaghan, K., Davey, M. And Cocking, E. 2000. The xylem of Rice (Oryza sativa) is colonized by Azorhizobium caulinodans. Proc. R. Soc. Lond. 267:103-107.

10.-O'Callaghan K. J., Stone P., Xiaojia H., Griffiths D., Davey M.R. and Cocking E.C. 2000. Effects of Glucosinolates and Flavonoids on Colonization of the Roots of Brassica napus by Azorhizobium caulinodans ORS571. Appl. Environ. Microbiol. 66(5):2185-2191.

11.-Ladha J., García M., Miyan S., Padre A. and Watanabe I. 1989. Survival of Azorhizobium caulinodans in the soils of rhizosphere of wetland rice under 
Sesbania rostrata-rice rotation. Appl. Environ. Microbiol. 55:454-460.

12.-Boivin C., Ndoye I., Lortet G., Ndiaye A., De Lajudie P. and Dreifus B. 1997. The Sesbania root symbionts Synorhizobium saheli and S. teranga bv. sesbaniae can form stem nodules on Sesbania rostrata, although they are less adapted to stem nodulation than Azorhizobium caulinodans. Appl. Environ. Microbiol. 63(3):1040-1047.

13.-Vasse J., Frey P.\& Trigalet A. 1995. Microscopic studies of intercellular infection and protoxylem invasion of tomato roots by Pseudomonas solanacearum. Molecular Plant-Microbe Interactions 8:241-251.

14.-Trouvelot A., Kough J.L. et Gianinazzi-Pearson V. 1986. Mesure du taux de mycorhization VA d'un système radiculaire. Recherche de méthodes d'estimation ayant une signification fonctionnelle. In: Physiological and Genetical Aspects of Mycorrhizae, V. Gianinazzi-Pearson and S. Gianinazzi (eds.). INRA Press, Paris, pp. 217-221

15.-Davey M., Webster G., Manders G., Ringrose F., Power J. and Cocking E. 1993. Effective nodulation of micropropagated shoots of the non-legume Parasponia andersonii by Bradyrhizobium. J. Exp. Bot. 44:863-867.

16.-Joy D., Pawley J.,B. 1992. Highresolution scanning electron microscopy. Utramicros. 47: 80-100.

17.-Cancino G. O. 2001. Tissue culture and Agrobacterium mediated transformation studies in Passiflora. Tesis Doctoral. University of Nottingham. U.K. 120 p.
18.-Cancino GO,Gill MIS, Anthony $P$, Davey MR, Lowe KC ,Power JB (2004) Naringenin enhanced efficiency of GUS activity in Passiflora mollissima (H.B.K.) Bailey. Universitas Scientarium Vol. 9 (1): 47-57.

19.-Nakajimaa, A, Aonoa T,Tsukadaa S, Siarota L, Ogawab $T$ and Oyaizua H.2012 Lon Protease of Azorhizobium caulinodans ORS571 Is Required for Suppression of reb Gene Expression Appl. Environ. Microbiol. September 1, 2012 78:6251-6261

20.-O'Callaghan K. J., Dixon R. and Cocking E. 2001. Arabidopsis thaliana: a model for studies of colonization by nonpathogenic and plant-growth-promoting rhizobacteria. Aust. J. Plant Physiol. 28:975-982.

21.-Webster G., Jain V., Davey M., Gough C. Vasse J., Dénarié J. and Cocking E. 1998. The flavonoid naringenin stimulates the intercellular colonization of wheat roots by Azorhizobium caulinodans. Plant Cell Environ. 21:373-383.

22.-O'Callaghan K. J., Dixon R. and Cocking E. 2001. Arabidopsis thaliana: a model for studies of colonization by nonpathogenic and plant-growth-promoting rhizobacteria. Aust. J. Plant Physiol. 28:975-982.

23.-Gough C., Galera C., Vasse J., Webster E., Cocking E. and Dénarié J. 1997. Specific flavonoids promote intercellular root colonization of Arabidopsis thaliana by Azorhizobium 
25

caulinodans ORS571. Mol. Plant-Microbe Interact. 10:560-570.

24.-Boivin C., Ndoye I., Lortet G., Ndiaye A., De Lajudie P. and Dreifus B. 1997. The Sesbania root symbionts Synorhizobium saheli and S. teranga bv. sesbaniae can form stem nodules on Sesbania rostrata, although they are less adapted to stem nodulation than Azorhizobium caulinodans. Appl. Environ. Microbiol. 63(3):1040-1047.

25.-Dreyfus B., García J.L. and Gillis M. 1988. Characterization of Azorhizobium caulinodans gen nov., a stem nodulating, nitrogen fixing bacterium isolated from Sesbania rostrata. Int. J. Systemat. Bacteriol. 38:89-98.

26.-De Hoff P. and Hirsch A.M. 2003. Nitrogen comes down to Earth: Report from the $5^{\text {th }}$ European nitrogen fixation conference. Molec Plan Interac 16 (5): 371-375.

27.-Goormachtig S., Capoen W., James E.K., Holsters M. 2004. Switch from intracellular to intercellular invasion during water stress tolerant legume nodulation. Proc. Nat. Acad. Sci. USA. 101(16) 6303-6308.

28.-Stone P.J., O`Callaghan K.J., Davey M.R. and Cocking E.C. 2001. Azorhizobium caulinodans ORS571 colonizes xylem of Arabidopsis thaliana. Mol. Plant-Microbe Interact. 14:93-97.

29.-Lin CC, Chen YC, Song SC and Lin LP (1999) Flavonoids as inducers of extracellular proteins and exoplysaccharides of Sinorhizobium fredii. Biol Fert Soi 30:83-89.
30.-Glick B. and Pasternak J.J 2003. Molecular Biotechnology. Third Edition. American Society of Microbiology Press. Hernson VA 20172, USA.760p
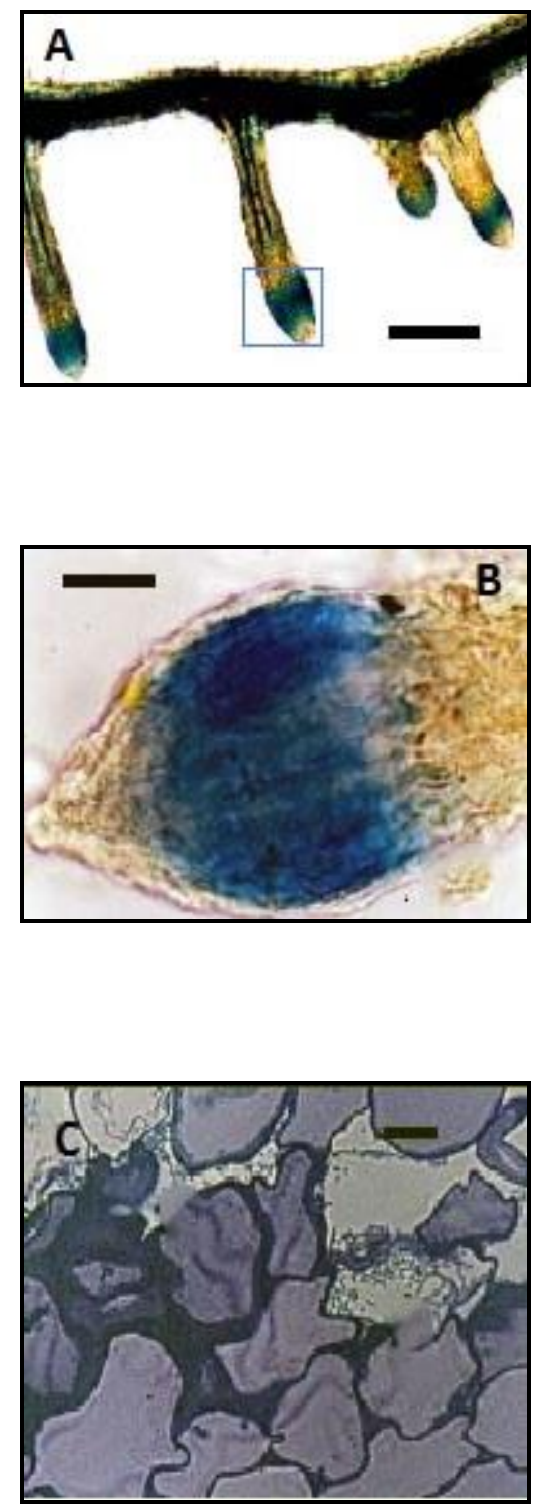
26

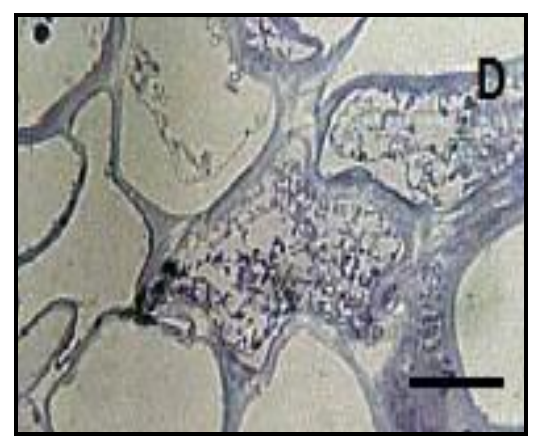

Figure 1. (A-B) Light microscopy of intercellular colonization of blackberry in vitro plants (varieties thorn and thornless) by Azorhizobium caulinodans ORS571 (pXLGD4) visualized by histochemical staining of bacterial B-galactosidase activity (blue colour) (A) Crack entry infection by azorhizobia into lateral roots (B) Root tip of lateral root colonization. Electronic microscopy of intercellular colonization $(C, D)$ with pockets of bacteria contained within an intercellular space. Scale bars: (A) $150 \mu \mathrm{m}$; (B) $25 \mu \mathrm{m}$.; (C) $15 \mu \mathrm{m}$; (D) 10 $\mu \mathrm{m}$. 